[ Preprint - Version auteur avant mise en page de l'éditeur ]

Matthieu Noucher. The Place Names of French Guiana in the Face of the Geoweb: Between

Data Sovereignty, Indigenous Knowledge, and Cartographic Deregulation. Cartographica, The International Journal for Geographic Information and Geovisualization, University of Toronto Press, 2020, 55 (1), pp.15-28. \{10.3138/cart-2018-0027) 


\title{
The place names of French Guiana in the face of the geoweb: between data sovereignty, indigenous knowledge, and cartographic deregulation
}

\author{
Matthieu Noucher \\ French National Center for Scientific Research (CNRS) - PASSAGES Joint Research Unit (UMR 5319) \\ Maison des Suds -12 esplanade des Antilles - 33607 Pessac cedex - France \\ matthieu.noucher@cnrs.fr - https://cv.archives-ouvertes.fr/matthieu-noucher - https://orcid.org/0000-0003-2101-2214
}

\begin{abstract}
French Guiana, the only overseas region of Europe located in South America, is faced with the claims of identity politics, particularly those of the indigenous peoples, who propose alternative place names. This critical analysis of the process for a posteriori recognition of toponyms is based on deconstruction of local, national, and international toponymic databases circulating on the geoweb, supported by interviews with the advocates of these corpora. We propose a critical analysis of toponymic data flows, examining how these data transit through the web and disappear into the limbo of the internet or gradually become definitive. This highlights the complexity of the current digital geographic information landscape: national institutes defend a form of data sovereignty for their territory, but they are caught between the digital empowerment of local communities now able to produce counter-cartographies and planet-wide cartographic deregulation emanating from the web giants.
\end{abstract}

\section{Résumé}

La Guyane française, seule région ultramarine d'Europe située en Amérique du Sud est confrontée à des revendications identitaires, en particulier celle des peuples premiers qui proposent des toponymies alternatives. Une déconstruction des bases de données toponymiques locales, nationales et mondiales qui circulent sur le géoweb couplée à des entretiens avec les promoteurs de ces corpus permettent de proposer une analyse critique des processus de reconnaissance des toponymes en aval de leur création. En s'interrogeant sur la façon dont ces données transitent sur le Web, disparaissent dans les limbes d'Internet ou font progressivement autorité, nous proposons une analyse critique des flux de données toponymiques. Celle-ci permet de souligner la complexité du paysage de l'information géographique numérique actuel : alors que les instituts nationaux défendent une forme de souveraineté informationnelle de leur territoire, ils sont pris en tenaille entre l'empowerment numérique des communautés locales qui leur permet désormais de produire des contrecartes et des dérégulations cartographiques planétaires issues des géants du Web.

Keywords: place name; critical toponymy; critical data studies; data flow; geoweb; indigenous knowledge; French Guiana

Mots-clés : nom de lieu, toponymie critique, études critiques de données, flux de données, géoweb, connaissances autochtones, Guyane française 


\section{Introduction}

Place names, as indicative not only of collective territorial imagination, but also power issues related to territorial marking, have long been subjected to analysis, not only in linguistics, but also in social sciences, particularly geography, anthropology, and also the history of cartography. Today, many studies emphasize the modern geopolitical stakes of toponymy, from a post-modern and/or post-colonial perspective, focusing on both the imagery conveyed and the resulting struggles and disputes (Kadmon 2000; Rose-Redwood 2006; Monmonier 2006). Ends of empires, the treatment of disputed territories, and the development of pioneered spaces (generally settlements) at a time of rehabilitation of the rights of indigenous peoples thus offer very interesting situations from this standpoint (Collignon 2006; Desbiens, Rivard and Hirt, 2018).

With the development of digital geography, the internet, and especially the geoweb, cartographic redefinition is on the increase (Dodge, Kitchin and Perkins 2009) and one may ask whether it modifies, diffracts, or even dilutes the power of place names. Indeed, a geographic item has become one piece of data among others in many of the tools of our digital life (Wilson 2017). Thereby, the development of both geographic information technologies and geographic information in technology conveys or produces purposes and uses that are not only increasingly varied, but also independent or emancipated from the expert approach historically associated with geomatics (Sui, Elwood and Goodchild 2013).

In view of the variety of stakeholders, we support the theory that, in addition to critical analysis of the meaning of toponyms (place names) and how they are created (place naming), it is now also necessary to analyze the power relationships that control their diffusion (place name flow). Our hypothesis is that the geoweb may prove to be a vector of domination, by reinforcing the authority of established place names and masking disputes, but, at the same time, it may also become a vector for resistance by offering alternative means of propagation.

To test this hypothesis, we analyzed the case of French Guiana, the only ultraperipheral region of the European Union in South America. From a toponymic point of view, it represents a particularly interesting, complex situation: pioneer place names dating from the colonial conquest are juxtaposed with indigenous place names. Official maps, however, by no means reflect this diversity. Consequently, the geoweb seems to represent an alternative diffusion channel for expressing the issues of knowledge and recognition of the various communities that make up French Guiana.

This research took its inspiration from critical data studies by attempting to decipher the many, complex blends that result from posting data on the web and 
analyzing their performativity to reveal the socio-spatial issues (Dalton, Taylor and Thatcher 2016). We adopted a mixed method, combining analysis of the web (exploration of data infrastructures) and interviews with the people who manage local, national, and international databases. Our aim was to compare the discourse of the data producers and the content that is actually propagated, visible, and usable on different levels. This exercise highlighted the potential for resistance offered by the geoweb, by facilitating recognition of place names outside official channels and, consequently, raised cartographic sovereignty issues.

In a first theoretical part, we defend our proposed critical analysis of the diffusion of place names to see how they adapt to the geoweb and new opportunities for propagation and accessibility of information. Thereafter, we present the case of French Guiana, based on an inventory of the cartographic and toponymic issues in this territory, and define the research method used to achieve a comprehensive analysis of the various sources currently available. The next part presents a multi-scale (local to national) analysis of toponymic databases. These observations are then discussed to highlight the dichotomy of the geoweb, between domination and resistance.

\section{A critical analysis of the circulation of place names: creation to imposition}

\subsection{Beyond place names and place naming: toward place name flow studies}

Neotoponymy is currently the subject of a great deal of research. It analyzes new place names that are not intended to take the place of existing ones but to designate emerging entities resulting from a reconfiguration of powers and their territories, via division and devolution of power (Guyot and Seethal 2007; Giraut and HoussayHolzschuch 2008). Place names thus appear to be the cognitive corpora of many social science studies, particularly political geography.

Political analysis of place names today tends to follow two different, yet complementary, approaches. Place name studies focus on the names themselves: collecting place names, decoding their meaning, and tracing their origin and history (Kadmon 2000). An increasing amount of this type of work mobilizes GIS to establish historical databases, making it possible to rewind the toponymic history of countries by exploring digital gazetteers (Goodchild and Hill 2008). Place naming studies focus on the procedure for giving a certain name to a specific place and the issues at stake. As such, "the name, which is the end product, might be even less revealing than the processes that led to the choice of one particular name and not others" (Giraut and Houssay-Holzschuch 2016). Frédéric Giraut and Myriam Houssay-Holzschuch proposed a conceptual framework, based on Foucauldian theory, particularly the concept of apparatus (dispositif), for comprehending place names as objects, place 
naming as a process, and the toponymic landscape (made up of names as they are used spatially or in mapping) as a whole or as a field of governmentality.

Governmentality has been defined as the art of governing populations by "conduct of conduct" (Foucault 1980). This involves using a set of power technologies to control and guide the choices and behaviors of populations, based mainly on a socially accepted structure of references. Cartography, especially through its use and promotion of toponymic corpora, drawing on identity, heritage and mercantile references, can thus be conceptualized as a technology of power. It spreads and disseminates political frames of reference that are "incorporated" in our everyday digital devices (from navigation systems in cars to smartphone applications that use geolocation) via addressing and data geo-referencing. These toponymic frames of reference thus seem to contribute to a form of algorithmic governmentality (Rouvroy 2011), by aggregating in databases - often global - and gradually imposing their world vision. Nowadays, any regulation of these frames of reference entails controlling their circulation on the web.

Consequently, we hypothesized that, in addition to critical analysis on the meaning of toponyms (place names) and their generation process (place naming), it was also necessary, in the internet age, to analyze their diffusion (place name flow), i.e. the way in which toponyms are disseminated, regulated, appropriated, and re-appropriated. Indeed, the use of these place names is imposed by their presence in the various databases on the geoweb. Consequently, understanding why different options for place names become visible or invisible involves decoding the power-plays that (also) occur on the internet.

\subsection{Toponymics in the face of increasing data flow}

Toponymic databases are made up of descriptive elements, including, at the very least, $[N, F, T]$, where $N$ is linked with the place name, $F$ represents its geographic location, generally its geographic coordinates (footprint), and $T$ refers to its type. In the 1990's, studies such as the University of California's Alexandria Digital Library $(A D L)$ project highlighted the major role of toponymic databases, which encode not only the relationship between the place name and its geographic position, but also establish a link between these elements and the type of place concerned (a river, for example). Goodchild and Hill (2008) thus emphasized the ontological power of these databases in influencing the way the world is formatted.

With the development of the geoweb, these toponymic databases are no longer only in the hands of cartographic institutes. Over ten years ago, Michael Goodchild (2007) published a reference text in the field of GIScience, presenting the concept of "volunteered geographic information" (VGI) to convey the technical and organizational reshaping that was disrupting the world of geomatics under the 
influence of web 2.0 (Turner 2006). Goodchild's text and the cohesive framework he proposed via the concept of VGI combined, in a single term, all the approaches for creating geo-located, voluntary, spontaneous content that now provide geographic data quite different from the conventional output of the sector's professionals. This positioning of the individual at the heart of geographic data production has generated a multitude of uses, characterized by the emergence of a whole string of expressions used to describe these developments, from user-generated geographic content ( $\mathrm{Xu}$ and Nyerges 2017) to geo-crowdsourcing (Sui, Elwood and Goodchild 2013). These terms emphasize the intrusion of web users in data production, from GIS/2 (Miller 2006) to neo-geography (Turner 2006) and highlight the break with "conventional" geomatics. In this context, the term geoweb (Leszczynski and Wilson 2013) has gradually gained ground, describing the changes perceived by both producers and users in geographic applications and data on the internet.

Faced with the geoweb, the (mainly national) institutions, which had previously devised, produced, and supplied the cartographic and toponymic references, are now challenged, rivalled, or even circumvented, by players with extremely varied statuses, natures, and motives (from Google to OpenStreetMap). Analysis of the toponymic landscape now necessitates deciphering these related databases and their associated data flows. French Guiana represents an ideal terrain for exploring these issues.

\section{Place names in French Guiana: knowledge and recognition}

\subsection{Guiana: between shortcomings and cartographic myths}

French Guiana, located at the heart of the Guiana Shield, is an overseas region of France, bordering on Brazil and Suriname (figure 1). It is the second largest region in France by surface area $\left(84,000 \mathrm{~km}^{2}\right.$, i.e. the equivalent of Austria). It is also the region with the second smallest population (just under 260,000 inhabitants, of whom nearly a quarter live in Cayenne). French Guiana, the only overseas region of the European Union in South America, offered several points of interest for analyzing updated cartographic production methods. Firstly, its geographic situation testifies to the challenges inherent in any cartographic ambitions: the extent of the territory, its low population density (3.2 inhabitants per $\mathrm{km}^{2}$ with hyperconcentration along the coast), cross-border interactions of all sorts with both Brazil and Suriname, and the difficulties of surveying the Amazon Basin. Its extensive cloud cover, makes it particularly difficult to obtain aerial photographs or satellite images, thus contributing to the significant challenges involved in gathering data. 


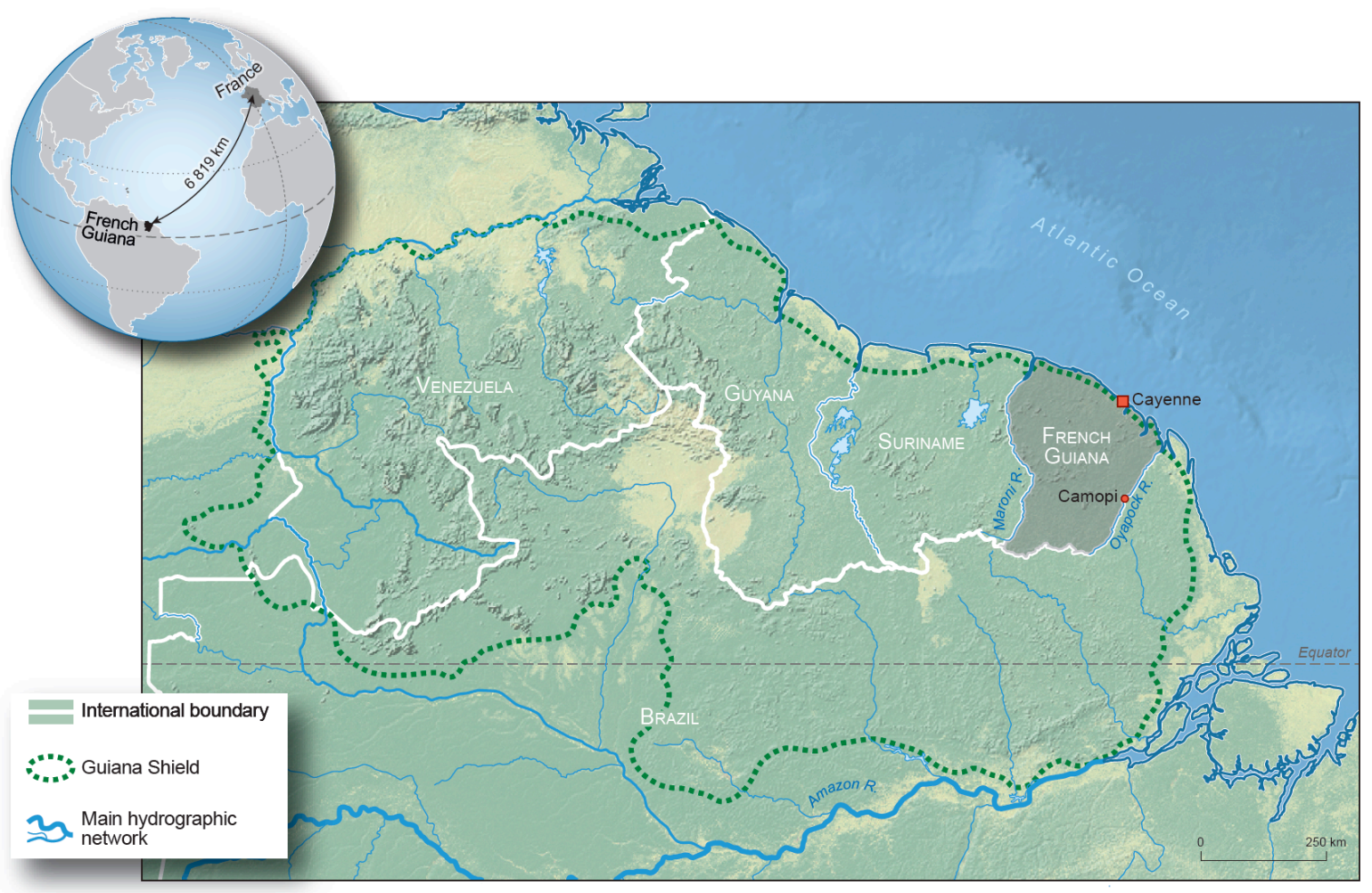

Figure 1. Situation of French Guiana on the Guiana Shield. Author: O. Pissoat, 2019.

Its history has been shaped by explorers' epic tales, accompanied by many cartographic myths, like the imaginary Tumuc-Humac Mountains, invented by military doctor Jules Crevaux and drawn by geographer and inveterate storyteller Henri Coudreau on his 1887 map. In the minds of Europeans, these faked maps nourished the image of Terra nullius (no man's land) and the green hell, depicted as hostile and impenetrable, but nevertheless enchanting, in the paintings of Henri 'Le Douanier' Rousseau'.

Many initiatives by government departments, scientists, and various associations have attempted to correct these gaps and persistent cartographic myths. Over the past decade, an increasing number of local mapping portals on the geoweb ${ }^{2}$ have produced data concerning this territory, complementing or interlocking with national or international data infrastructures. Consequently, French Guiana presents an interesting laboratory for decrypting the data flows across the web, especially with regard to place names.

\footnotetext{
${ }^{1}$ A series of canvases by Rousseau depict exuberant tropical jungles, often illustrating struggles between wild animals and their prey (Le lion, ayant faim, se jette sur l'antilope / the hungry lion attacking the antelope, 1898/1905, oil on canvas, $200 \times 301 \mathrm{~cm}$, Fondation Beyeler, Riehen/Bâle). They were inspired by his excursions... to the Paris Botanical Garden and Tropical Garden or by botanical reviews of the era, since Rousseau never set foot in French Guiana.

${ }^{2}$ For example: https://www.geoguyane.fr/ or also http://www.guyane-sig.fr/
} 


\subsection{The toponymic situation in French Guiana}

In 2016, geographer Roger Brunet published a dictionary of France's place names. Over 700 pages long, it provides detailed descriptions of the place names in France's mainland and overseas territories. Just one small page is devoted to French Guiana and its interior is rapidly dismissed out of hand with this incontrovertible sentence: "Vast regions are exempt of inhabitants and place names, at least with regard to detailed maps" (Brunet 2016: 591-592). Brunet took the wise precaution of stating that his observation is valid "at least with regard to detailed maps" for, as he explained in the foreword to his work, his method for recording place names involved exploring the IGN Géoportail ${ }^{3}$, an institutional website that provides access to the major French maps. Indeed, Brunet saw very little on these maps: the IGN possesses very little data on the interior of French Guiana, as previously observed by Lézy (2000). The latter identified 775 French place names on the 1:500000 map produced by the IGN in 1995, of which three quarters were nicknames, i.e. terms directly interpretable without any need to analyze their etymology. They are divided into three main families: discovery of the forest with references to journeys, animals, and landscapes; gradual occupation of land with references to work, peoples encountered, and baptism (a series of place names commemorate births); and, finally, the mental images applied to places, with names referring to heaven and hell, as well as external references imported into French Guyana to impress people and mark these sites.

The place names on the IGN maps are concentrated on the coast and along the two rivers that mark the borders. The inland regions thus remain little known, even if very occasional excursions were undertaken throughout the $19^{\text {th }}$ and until the mid- $20^{\text {th }}$ centuries. They focused on gold-mining areas, as shown today by the toponymic heritage of places with evocative names: "Bœuf-Mort" (dead ox), "Panne" (breakdown), "Bon secours" (good comfort), "Bon espoir" (good hope), "Patience", "Certitude" (certainty), "Enfin" (finally), "Repentir" (remorse), "Misère" (poverty), "Folie" (madness), etc. (figure 2). Taken together, these French place names provide an insight into the history of migration, namely the gradual movement of the French colonists into the forest... This migration was often very cautious and a religious quest may, in fact, have been the logical conclusion of this often disappointing exploration, evidenced in place names such as "Diable" (devil), "Elysée" (Elysium), "Enfer" (hell), "Autel" (altar), and "Trinité" (trinity)... Thus French Guiana often provides us with somewhat comical toponymic landscapes, such as "Mont Respect" (mount respect) located in the heart of the "Massif Lucifer" (Lucifer range).

\footnotetext{
${ }^{3}$ https://www.geoportail.gouv.fr/
} 


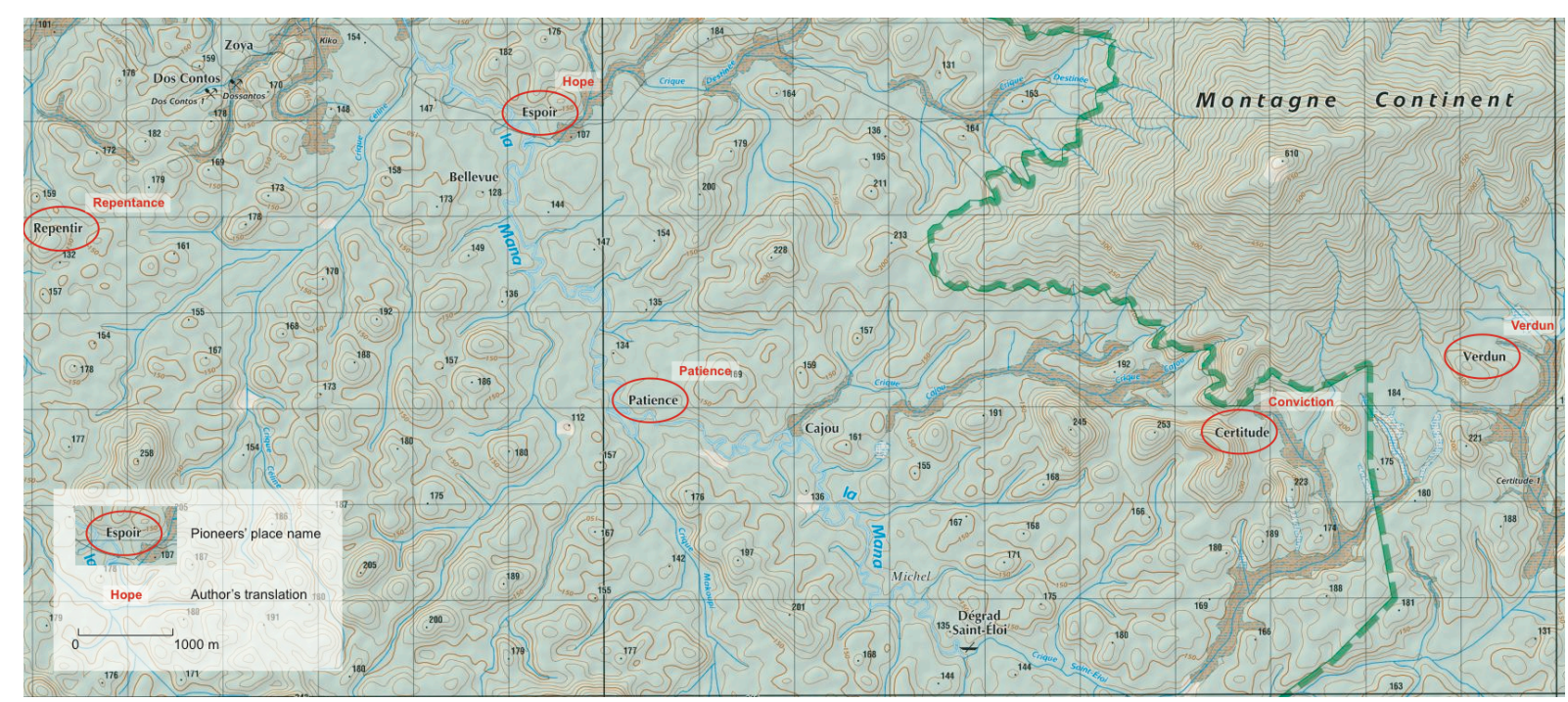

Figure 2. Extract of the IGN topographical map - available on http://geoportail.gouv.fr - highlighting the French place names associated with the conquest of inland French Guiana. Source: () IGN 2019.

These symbols of inland French Guiana bear witness to the incapacity of the pioneering experiences to decode indigenous markers. Yet the current toponymic landscape of French Guiana is characterized by its wealth and diversity, featuring Amerindian, Brazilian, Surinamese, Creole, Bushinengue, and $\mathrm{H}^{\prime}$ mong influences. Consequently, in addition to French place names, French Guiana boasts many indigenous place names. This is even one of the characteristics of the Guiana Shield that sets it apart from the rest of Latin America or the Caribbean: the significant number of place names originating from indigenous communities, as highlighted by the historian and specialist on French Guiana, Vere Daly: "Although the English, Dutch and French have left their mark on the country in the form of place-names, Amerindian place-names still predominate. From the time we leave the coastlands there is scarcely a name we encounter that is not Amerindian in origin" (1976: 20).

\subsection{Exploratory analysis focused on the circulation of maps}

Whilst national institutional maps seem to give little reflection of this toponymic diversity, by partially rendering indigenous place names invisible, other maps are now accessible on the internet. Might these maps, established using international or community-derived databases, become a counter-power and offer an alternative cartography, enhancing recognition of indigenous place names? Does the emergence of new cartographic creation and dissemination systems, together forming the geoweb, represent continuity or contradiction with previous systems, particularly those dating from the period when cartography was a practice reserved for the most powerful stakeholders, including the state? Finally, does the geoweb reveal geomedia forms as alternatives to the dominant output?

To try and answer these questions using the case of French Guiana, we undertook exploratory research based on critical data studies. This type of analysis deconstructs 
the contexts of production, analysis, dissemination, and use of data on web infrastructures to reveal the underlying political issues (Iliadis and Russo, 2016). We adopted a mixed method, combining analysis of online toponymic databases with interviews of the people who manage these local, national, and international resources. The databases were explored by extracting available data from various web portals and analyzing their content.

The interviews were conducted in Paris at the IGN head office, the toponymic committee, and the Ministry for Ecological and Inclusive Transition, the authority responsible for supervising these two structures. Lastly, local interviews were conducted with decentralized government departments, the Guiana Amazonian Park, representatives of indigenous communities, and scientists, during four missions, between 2015 and 2018. These repeated missions retraced the steps in the place names' life cycle, so as to reconstruct the lines of tension along which the various databases emerge on the geoweb, clash, and intertwine. Our aim was to confront the discourse and imagery of the data producers on different levels with the visible, usable content that is actually disseminated.

\section{Multi-scale deconstruction of toponymic databases}

\subsection{A participatory mapping initiative at local level to preserve memoryscapes}

Contrary to the common preconception widely conveyed by the IGN maps, the French Guiana forest is not a virgin territory with a few rivers named by explorers in past centuries. The way of life of communities in southern French Guiana is founded upon a "territory of resources", which meets the needs of these forest communities in many ways. Consequently, every creek, each plot of land suitable for cultivation and each clump of "arouman" plants, used for wickerwork, possesses a specific character, history, and place name that expresses part of the communal memory. We can see similarities with research conducted in other Indigenous communities, such as English anthropologist Mark Nuttall (1991) and French geographer Béatrice Collignon (2006), whose work on the vernacular geography of the Inuinnait is partly based on an analysis of place names. Consequently, in French Guiana, as in the Arctic, the memory of indigenous communities is inscribed in the history of the territory and, to an even greater extent, its toponymy. Place names organize and socialize this territory. They distil the memory of the men and women associated with the various places into one or two words - which may equally refer to simple geographic terms, practices, or a story, without needing to substantiate it in visible forms or human constructions. Mark Nuttall writes of the "hidden meaning" of place-names and refers to named landscapes as "memoryscapes" (1991).

With the aim of preserving this living cultural heritage and facilitating recognition of the occupancy of this territory by Amerindian communities, the Guiana Amazonian 
Park (PAG) launched a vast participatory mapping project, completed in 2014, with the Teko and Wayãpi communities on the southern border of French Guiana. By capitalizing on various records compiled over the past fifty years and making systematic recordings via GPS between 2009 and 2011, the PAG, in partnership with the French National Center for Scientific Research (CNRS), was able to draw up maps of the municipality of Camopi (figure 3), including almost 600 different place names transcribed from the Wayãpi and Teko languages. The Wayãpi and Teko (formerly called the Oyampi and Emerillon) are two Amerindian peoples in the Tupi-Guarani family, widespread in Brazil. Their languages display significant phonetic, lexical, and grammatical differences. Over the past two centuries, the territories of the Wayãpi and Teko in French Guiana developed around the Oyapock River and its tributaries, including the Camopi River, which forms part of the border with Brazil. Today, over 1,700 inhabitants roam this vast territory ${ }^{4}$, drawing from it a considerable share of the resources essential for their way of life. Their long-standing, intimate knowledge of falls, tracks, hunting trails, gathering and fishing zones, ancient villages, etc., is conveyed through the extremely high number of place names that punctuate the territory.

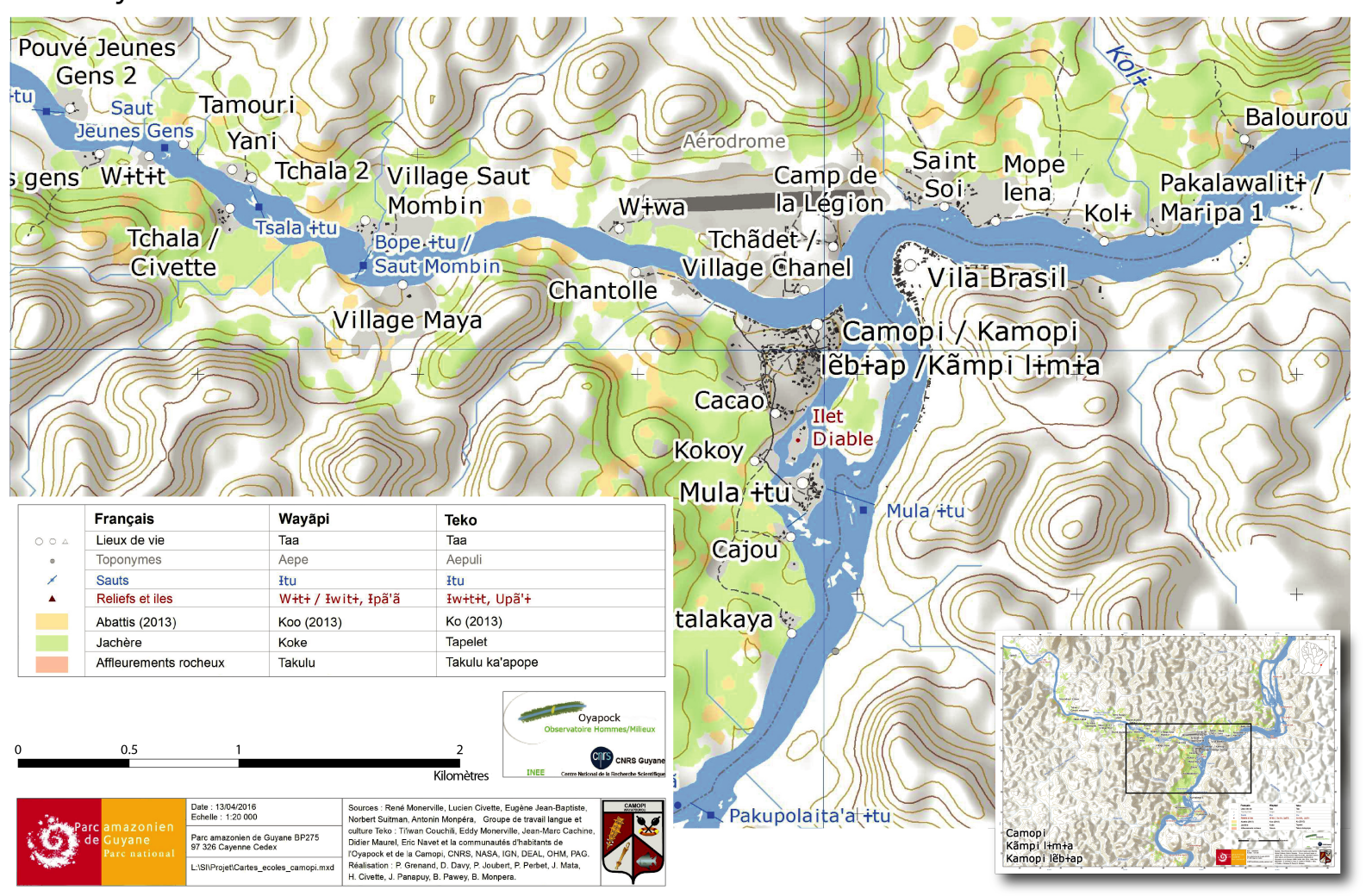

Figure 3. Extract of a map of Camopi, showing place names, waterfalls, relief, and living places in three languages (French, Wayãpi, and Teko). Note the considerable number of contributors indicated in the map sources. Sources: (c) Parc amazonien de Guyane; René Monerville, Lucien Civette, Eugène JeanBaptiste, Norbert Suitman, Antonin Monpéra, Groupe de travail langue et culture Teko: Ti'iwan Couchili, Eddy Monerville, Jean-Marc Cachine, Didier Maurel, Eric Navet and the communities of the people of the Oyapock and the Camopi, CNRS, NASA, IGN, DEAL, OHM, PAG. Production by $P$. Grenand, D. Davy, P. Joubert, P. Perbet, J. Mata, H. Civette, J. Panapuy, B. Pawey, and B. Monpera.

\footnotetext{
${ }^{4}$ Camopi is the $3^{\text {rd }}$ largest municipality in France by surface area, over $10,000 \mathrm{~km}^{2}$.
} 
Whilst the Wayãpi and Teko place names reflect their spatial specifics, they also illustrate the territory's mythical and cultural geography (Grenand and others 2017). The secondary waterways and waterfalls are clearly the zones with the most place names, giving genuine structure to the Amerindian territory. The village place names are often derived from the name of a tree (such as Monbin on the middle section of the Oyapock River) or refer to their founder (such as Zidock, in reference to Zidock Yawapini). The plant world boasts a strong presence, indicative of these people's indepth knowledge of the resources they use on a daily basis. Legendary places often refer to imaginary animals and are a testament to more ancient occupancy than that of the current societies. Lastly, recent historical episodes are also frequently commemorated. As emphasized by a specialist of the Oyapock River who took part in the process: "place names showcase indigenous, ancestral, and everyday knowledge and form an integral part of the history of these so-called 'history-less' peoples"

In 2012 and 2013, several meetings took place in Cayenne and the Camopi communities to verify all the data. The contributors to this participatory mapping approach are indicated in the map legends. The PAG then made considerable efforts to promote these new elements of knowledge, by publishing guides, organizing many presentations, and printing maps for the schools in inland French Guiana (Grenand and others 2015).

To ensure recognition beyond the local context, the PAG also transmitted its database to the IGN. We therefore analyzed the downstream part of the place-name creation process, namely the effects of circulating these data, with the aim, shared by this project's promoters and participants, of transforming this knowledge into recognition, by attempting to have them gradually incorporated into the official frames of reference. As explained by the PAG's GI Scientist: "There was genuine enthusiasm for this project: in the current context, with so many issues related to land and language, promoting the toponymic wealth of one's territory is a veritable act of political and cultural life". Integration of this local toponymy into official maps therefore quickly became a recognition issue.

\subsection{Sovereignty is the key issue at the national level}

The French State's institutional maps display a striking contrast between the paucity of their content (mentioned by R. Brunet - cf. section 3.2) and the wealth (in terms of density and linguistic diversity, as well as the historical and mythical depth) of common place names strewn through French Guiana (from the coast to inland areas and from Maroni to the Oyapock River). However, the IGN place names are not set in stone, but updated regularly, as shown by the collection of 1:50000 maps published in 2015.

\footnotetext{
${ }^{5}$ Interview with Damien Davy, anthropologist at the CNRS, Cayenne on December 5, 2017.

${ }^{6}$ Interview with Pierre Joubert, GIScientist for the PAG, Remire Montjoly, on Mai 16, 2018.
} 
France was required to produce a 1:50000 map of the country as part of its NATO membership. In French Guiana, in the absence of aerial photography covering the entire territory, an assembly of data produced by the Ministry of the Environment and the Ministry of Defense was used to produce this cartographic patchwork. In certain sectors, the military place names dotting the map are totally fanciful. For example, in the area around Saül, some sites correspond to points geo-tagged by the Armed Forces of French Guiana and indexed as Saül_1, Saül_2, Saül_3, Cambrouze SudOuest_1, etc. (figure 4), but make no sense from a toponymic point of view...
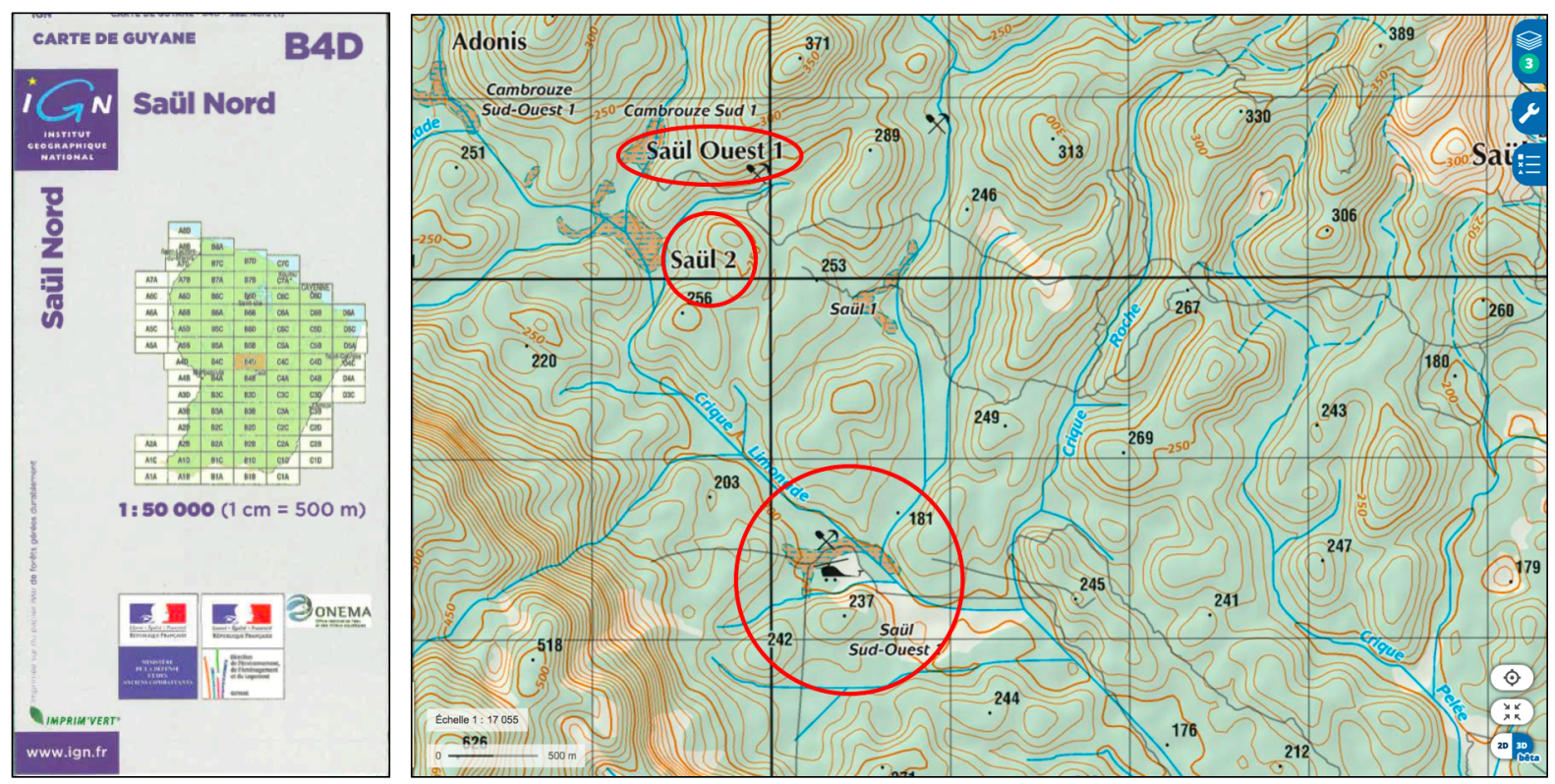

Figure 4. The inset on the 1:50000 IGN map published with the assistance of the Ministries of Defense and the Ministry of the Environment (logos). Its publication on the geo-portal (screen capture on the right) illustrates the toponymic diversity of the surroundings of Saül! Source: @ IGN 2019.

Indeed, the military provided their entire database to the IGN, containing, in particular, a series of geo-tagged points where a helicopter could land, generally at former placer mining sites ${ }^{7}$. The IGN then incorporated these elements en masse. Even the military were surprised to see these sites on the map and listed as place names in the index: "The names of these geo-tagged sites originated from our maiden ground missions. When we saw them appear on IGN maps, we were the first to be surprised and we told the IGN they should have been more selective!" ${ }^{\prime \prime}$. We are therefore faced with a very inadequate map from a semantic standpoint, especially in terms of Amerindian place names. Yet, today, it still remains one of the reference maps for the territory of French Guiana.

In view of this lack of consideration for inland French Guiana, the local stakeholders attempted to explain the importance of recognition for their initiative to the IGN.

\footnotetext{
${ }^{7}$ Placer mining is the mining of stream bed deposits for minerals. This may be done by open-pit or using various surface excavation or tunneling equipment.

${ }^{8}$ Interview with the Intelligence Bureau (J2) of the High Command of the Armed Forces in French Guiana (COMSUP), Cayenne, on $18^{\text {th }}$ May 2018.
} 
So, although the transcription into writing is very recent ${ }^{9}$, the PAG emphasized that significant enthusiasm had been shown by the Teko and Wayãpi populations: the local education system has adapted to the situation with the recruitment of bilingual mediators in 1998, who became mother tongue contributors in 2007. In this context, the PAG deems that "the introduction of a new gallicized written form of Teko and Wayãpi words would be extremely harmful"10. Its consequence would be to "stir up trouble and confusion, calling into question this scriptural construction painstakingly elaborated by specialists with the cooperation of the native speakers themselves". The idea of translating place names is no more tenable for the PAG: "This initiative would be seen by the native speakers as a new way of depreciating their language in relation to French, and, by the people of French Guiana as a whole, as an umpteenth attempt at cultural subordination". Despite these arguments, the request for recognition failed. Indeed, a comparison of the IGN data from September 2017 (BD TOPO) with that of the PAG (BD PAI) reveals a clear discrepancy, particularly in southern French Guiana, especially around Camopi (figure 5).

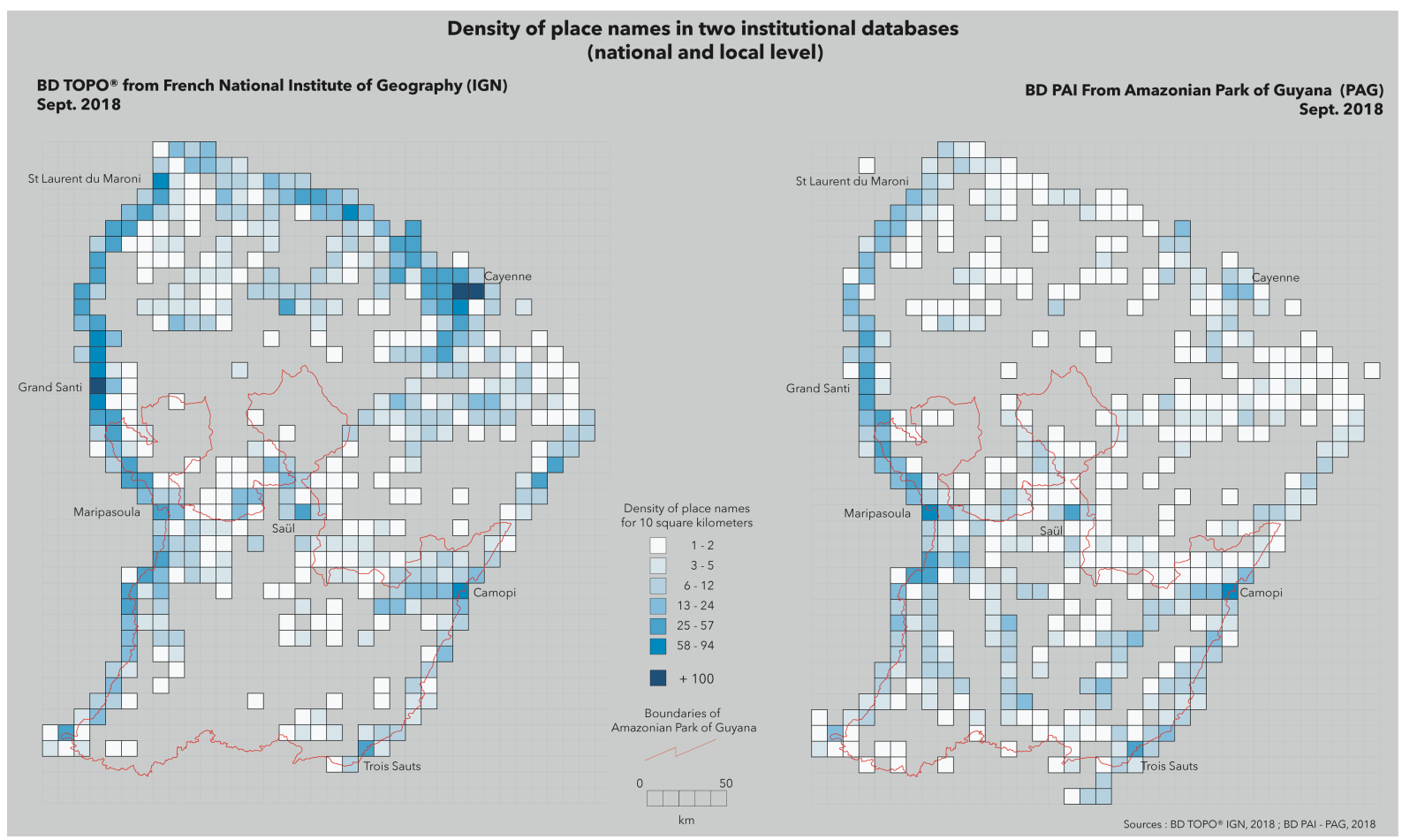

Figure 5. Comparison of the distribution of place names between the IGN and PAG databases. The circled zones highlight the considerable variation between these two databases in inland French Guiana, especially to the south of Maripasoula and Camopi. Author: Matthieu Noucher, 2019.

The reasons for this refusal were twofold. The IGN explained that out of 650 place names it refused to incorporate, 350 were of "disputed legitimacy" and 324 were "technically disputed", with some place names concerned by both objections. The place names of "disputed legitimacy" concerned places already named by another

\footnotetext{
9 The Wayãpi and Teko communities are said to be, as is the case for the whole of the Amazon region, "peoples of oral tradition". Transcription into writing is a very recent occurrence: the first Wayãpi language dictionary, published in 1989, includes more than 6,000 words (Grenand, 1989).

${ }^{10}$ Interview with Pierre Joubert, GIScientist, PAG, Rémire Montjoly, Mai 16, 2018
} 
source, which required two different sources to be modified. The weight of the past and the difficulty of challenging the names given by exploring colonialists are both evident here. It reflects "the dizzying longevity of place names"11, according to the formula used by the Chairman of the French National Toponymy Commission (CNT), who considers that one of the main missions of the CNT is precisely to ensure the stability of the names it validates. The "technically disputed" place names concerned characters specific to Amerindian languages that apparently did not comply with international standards. The latter of these arguments refers to a phoneme shared by Teko and Wayãpi that does not have a written translation in French. It is a vowel between " $i$ " and " $u$ ", noted by convention with an " $i$ bar tilde". The tilde is a diacritical sign, i.e. it is used on a letter to modify the pronunciation and, in this specific case, to produce a nasal vowel. The IGN deemed that this notation was not compliant with existing standards and stated that: "The process implemented by the IGN demands that the characters used are compliant with data storage standards and respect the State's general interoperability database (RGI)"12.

However, the Unicode international consortium that sets the ISO/IEC 10646 standard for exchanging texts in different languages, on which the RGI is based, included the "I bar tilde". Indeed, this standard is based on the International Phonetic Alphabet (API), where the code of a diacritic sign is allowed to be combined with another letter. Therefore, on the face of it, there is no problem regarding compliance with standards. Having countered the IGN's technical argument, discussions with the French National Toponymy Commission in Paris produced another explanation. Seen from Paris, it is apparently difficult to understand that there can be so many Amerindian place names and that place name density is higher in Camopi than Cayenne. The obstacle may also be methodological: "At the IGN, there is a map culture rather than a database culture. Since French Guiana has been mapped at a very small scale, it is not practical to put too many place names on the map"13. The IGN only produces small-scale maps of French Guiana: a general 1:500000 map and ten 1:200000 spatiomaps. In addition, the IGN has also produced other series from time to time: three 1:100000 tourist maps along the coast, six 1:100,000 maps of the west, a 1:25,000 tourist map of Cayenne and a 1:5,000 map of Kourou. The 1:25000 topographical reference maps only cover the coastal strip. The need for "toponymic coverage" is, therefore, limited. However, digital databases are far more widely disseminated today than simply static maps. On further investigation, these material considerations soon gave way to geopolitical issues: "The act of naming a place may one day serve to establish territorial claims. Toponymy therefore involves a genuine issue of sovereignty, particularly in border areas $^{\prime 14}$. The abundance of mineral resources in the Guiana Shield region, at the crossroads of three strategic zones (the Amazon Basin, the Caribbean, and Europe), makes it the focus of many territorial claims. French Guiana and Suriname thus recently

\footnotetext{
${ }^{11}$ Interview with Pierre Jaillard, Chairman of the French National Toponymy Commission, Paris, $21^{\text {st }}$ February 2018.

12 Letter from the IGN Reference System Production Division, dated $1^{\text {st }}$ October 2015.

${ }^{13}$ Interview with Pierre Jaillard, Chairman of the French National Toponymy Commission, Paris, le $21^{\text {st }}$ February 2018

${ }^{14}$ Interview with Pierre Jaillard, Chairman of the French National Toponymy Commission, Paris, le $21^{\text {st }}$ February 2018.
} 
signed an agreement (Nov. 2017) on their maritime border but have not yet settled their southern land frontier. The indigenous toponyms that Paris refused to integrate were on the border with Brazil, far from this disputed area. This border was fought over for centuries, until the treaty of Utrecht, signed in 1900, after a map battle between Vidal de La Blache on the French side and Rio Branco on the Brazilian side finally settled the fate of this region of the globe. However, dissertations by French cartographers reveal that this defeat is still painful, resulting, even today, in the refusal to recognize toponyms considered "exotic" in a region that is still "potentially conflictual".

Faced with this institutional blockage, the geoweb could be envisaged as a bypass route for extensive dissemination of toponymic registers that have a high heritage value but are not official or are considered secondary. However, it remains true that power plays are - also - exerted on the internet.

\section{The geoweb: between domination and resistance}

\subsection{The geoweb or how cartographic authority is reinforced on the internet}

Since locally-produced databases of place names could not be integrated into the national database, the PAG took on the task of disseminating them. Nonetheless, to avoid losing them in the ether of the internet, the institutional geoweb was chosen for a first trial, via the GéoGuyane portal ${ }^{15}$. This public platform, administered by the local services of the French state, is the Guianese side of the European spatial data infrastructure, implemented since 2007 as part of the INSPIRE directive ${ }^{16}$. This regulatory framework is intended to foster the re-use of institutional spatial data by encouraging their dissemination and facilitate access by defining technical specifications. In France, the national Géocatalogue ${ }^{17}$ acts as the intermediary between the European portal and the regional infrastructures, which, in turn, draw on local infrastructures. This stacking of platforms, feeding data from local to European level, operates using "harvesting" techniques that gather the data as soon as they are published on standardized infrastructures. Incorporating its toponymic database into GéoGuyane was therefore a symbol of official recognition of the PAG's work, by the assurance of its dissemination on national and European portals, thus increasing the possibility that their data would be re-used. However, in practice, the operation proved to be much riskier...

Consequently, to respect the layered functioning of geographic information systems, the initial map was split into three distinct series: place names, living places, and falls. The PAG, as custodian of this data, took the commendable precaution of

\footnotetext{
${ }^{15}$ http://www.geoguyane.fr/

${ }^{16}$ Directive 2007/2/EC of the European Parliament and Council dated $14^{\text {th }}$ March 2007, establishing a geographic information infrastructure in the European Union (INSPIRE): http://inspire.ec.europa.eu/

${ }^{17}$ http://www.geocatalogue.fr/
} 
also introducing the full map into the GéoGuyane map library, a collection of PDF maps. However, the fragmentation of the data and its dissemination in the form of separate GIS layers, due to technical constraints, now makes it possible to use them separately. Thus, the reductionism of a map that divides, separates, and organizes is reinforced by the malleability of the digital format, which facilitates further fragmentation. Furthermore, in the quest for exhaustiveness and simplification, the data from the participatory process was merged with other data sources to form a single file on the scale of the National Park, forming a compilation of GPS readings made by park agents, reproductions of old IGN maps, pronouncements by experts from the Museum and, finally, information gathered from the Teko and Wayãpi communities. This twofold data fragmentation/merger movement illustrates both the malleability and potential for hybridization of digital data on the web (Noucher, 2017).

The harvesting of the local SDI (GéoGuyane) by the national SDI (GéoCatalogue) presented an opportunity to observe a second stage in the circulation of Amerindian place names. Indeed, the primary purpose of the national catalogue is to disseminate spatial data for use in a GIS, rather than completed maps ${ }^{18}$. The gazetteer's map thus disappeared and the GéoCatalogue harvested the data selectively, conserving only the three "raw" spatial databases. Moreover, the simplified metadata on the web no longer indicated the pedigree of the data: the multiple and individual sources that appeared on the initial map had disappeared, leaving only a "point of contact", required to explicitly refer to a specific body. The standard, therefore, forces contributors of jointly produced data in a participatory system to be listed under the same "label" and individual, indigenous knowledge is thus diluted as a result of standardization.

The national GéoCatalogue itself is harvested by the government portal dedicated to open data ${ }^{19}$. Since late 2011, this platform, developed by Etalab, a mission under the authority of the Prime Minister, has disseminated (not exclusively spatial) public data, also known as "open" data. Once again, selection occurred and the PAG output, together with all the content from GéoGuyane, was not retrieved. This omission was ostensibly on legal grounds, as the data disseminated by GéoGuyane is not formally covered by an open license for commercial use. The government platform did not, therefore, include this information. Consequently, through incorporation into interconnected platforms, certain place names (such as those given by the military) became accessible in databases that have a monopoly and organize space. These place names thus obtained considerable digital visibility, whilst the omission of other datasets, such as those of the indigenous peoples, made them invisible and excluded them from the digital world. This situation, however, is not limited to institutional infrastructures.

18 In July 2015, 49,808 data items were inventoried in the GéoCatalogue for 724 maps.

19 https://www.data.gouv.fr 
Whilst the regional and national spatial data infrastructures eradicated Amerindian place names, thus reproducing their lack of visibility on the official IGN maps, the geoweb is characterized by the emergence of international platforms that seem to offer potential alternative channels for disseminating this type of data. A sort of cartographic deregulation has apparently been under way over the past fifteen years, thanks to worldwide commercial initiatives by the web giants that supplement, bypass, and now directly rival the institutional cartographic frames of reference. Recent analysis has shown that, in North American cities, for example, Google Maps has now become the primary arbiter of place names. ${ }^{20}$

In parallel with the development of these private services, civic initiatives have emerged, also on a worldwide scale. OpenStreetMap (OSM) is the most emblematic of these. Its growing development (in terms of contributor numbers, spatial coverage, and content quality) and open license have made it an increasingly widely-used data source. Furthermore, like Wikipedia, the online collaborative encyclopedia, OSM enables web users to contribute to a collective project via many interfaces: online data editors for adding or updating (graphic or alphanumeric) content, tools for importing GPS traces or data from open data portals, applications dedicated to data quality control, an API to encourage reuse of the database, a wiki-type site for accessing the data history, and dashboards for following contributor activity in real-time, as well as multiple communication channels (mailing list, forum, annual State of the Map conference, monthly meetings of local groups, etc.) to bring together the community.

It is precisely this set of technical, legal and organizational considerations that are currently encouraging the PAG to focus on this cartographic environment. From a technical point of view, the "i bar tilde" is not problematic and the OSM template even manages multilingualism. From a legal perspective, the Open Database License (ODbL) provides all the necessary guarantees for facilitating data reuse and quoting of sources. Finally, from an organizational point of view, integration of the data into a collaborative environment makes it possible to extend and expand the participatory dynamics to other potential contributors.

In addition to these technical, legal and organizational considerations, the growing institutionalization of OpenStreetMap today makes it a tool for disseminating and obtaining recognition of the work accomplished. Indeed, the OSM community is gradually becoming much more than a small group of ground-breakers, as demonstrated by the national and international State of the Map conferences, involving independent developers, private companies (associated with the open source domain and proprietary geomatics), as well as an increasing number of

\footnotetext{
${ }^{20}$ Article by Jack Nicas in the New York Times published on $2^{\text {nd }}$ August 2018 : 
academics and representatives of public authorities (Duféal and Noucher, 2017). The Canadian government statistics agency recently launched a participatory cartographic approach based on $\mathrm{OSM}^{21}$. The French government has finally paid serious attention to these initiatives, long considered trivial. However, the authorities still seem to view OSM as a competitor, rather than a potential partner. This attitude is evident in the evocative title of a recent parliamentary report intended to reposition the IGN in relation to these new cartographic practices: "Sovereign geographical data"22. Thus, as an alternative to the slowness and many blockages in the official channels, the Teko and Wayapi communities in French Guiana are following a parallel path over which they retain control, gradually disseminating their data and hoping that it will become established in the end. The ease of access to OpenStreetMap data considerably expands the potential for dissemination. Whereas, until now, maps were considered authoritative on the basis of their official character, they now acquire a new form of authority from the capacity to access and reuse their geographical data. From this perspective, OpenStreetMap seems to be a serious challenger to the IGN, even within French government departments. Although they were not accepted in the official database (BD TOPO), the Amerindian toponyms have indeed gradually been integrated into maps produced by private organizations and associations, as well as government authorities keen to be close to users. Interesting examples include: tourist maps of hiking trails produced by tourist information offices, a hydrological map produced by a local administration, and even maps showing access to health care circulated by the Regional Health Agency (ARS).

While for a long time the range of geographic reference documents available to cartographers mainly comprised "off the shelf" products with both a scientific and institutional character, alternative means of mapping space are gradually asserting themselves and bypassing official bodies (figure 6). In this way, OpenStreetMap contributes to a sort of "bottom up" cartographic deregulation, which, thanks to its militant dimension, may be considered a method of counter-mapping.

\footnotetext{
${ }^{21}$ https://www.statcan.gc.ca/fra/approcheparticipative

${ }^{22}$ Faure-Muntain V. (2018). Les données géographiques souveraines. Ministry for Ecological and Inclusive Transition Government of France. July 2018, 69 p.
} 


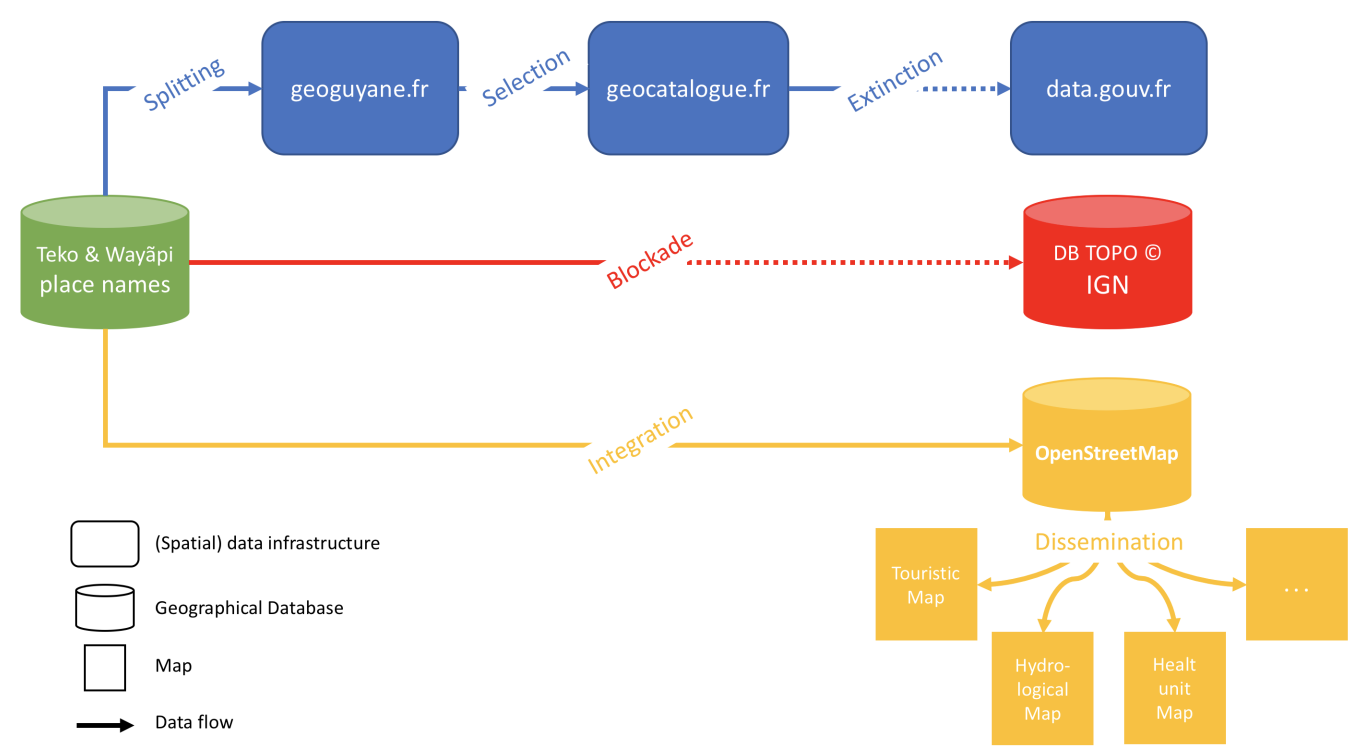

Figure 6. The various attempts at disseminating the indigenous place names of French Guiana along the interwoven strands of the geoweb. Author: Matthieu Noucher, 2019.

\section{Discussion. Toward a more realistic description of socio-political effect of toponymy: tracking place name flows}

The ease of producing and disseminating spatial data on the web contributes to reinforcing the capacity of non-specialists in cartography to regain the power to map their own territory and disseminate their own representations. It is also part of a process of emancipation and empowerment. However, at the same time, in order to be visible in public debates and exist among this myriad of "small maps on the web" (Noucher, 2017), it is necessary to use "tools" recognized by the powers that be. In doing so, the geoweb has relaunched the debate on the process of cultural assimilation of indigenous people via technology, which began in the early 1990's (Rundstrom, 1995). In French Guiana, as elsewhere, the geoweb, therefore, conveys a paradoxical promise: it offers a diverse range of spatial representations, whilst highlighting content that is more formally uniform.

Analysis of the control of toponymy in French Guiana and deconstruction of IGN maps raises questions concerning the way the French State seems to be prolonging the colonial legacy, even today. Whilst the inscription of local place names on maps published by non-native authorities is a potentially efficient means of reconquering the indigenous identity (Müller-Wille, 2000), in French Guiana, this process seems to be blocked by issues of information sovereignty. However, cartographic deregulation is accelerating thanks to socio-technical changes and the emergence of players with a worldwide influence, from Google to OpenStreetMap. This situation calls for a global rethink of information governance in territories (Mol, 2009). In light of these factors, earlier critical place naming studies seem too static. They paid no attention to digital developments and the data flows generated by expanded internet use. By 
concentrating on the social and political intentions of the cartographers, they forgot that the performativity of maps now depended on the interplay of internet data regulation. Through this case study, we proposed to adopt a different, yet complementary research approach: analyze the data life cycle, not focusing on the official recognition of toponyms or the creation of neotoponyms, but deciphering their digital trajectory (from diffusion to reuse/poaching to blocking) to reveal new forms of government by algorithm.

The self-referential power of a place name on a map is today reinforced by the twofold effect of the web and its economy. On the one hand, the ease with which digital content can be spread generates accelerated dissemination of data. On the other hand, from the moment a dataset becomes authoritative, its constant recycling through these interconnected systems swiftly puts it in an almost monopoly position, resulting in de facto reinforcement of its accompanying appearance of truth. This twofold effect (acceleration of dissemination and monopoly position) today strengthens the ontological power of maps and related digital gazetteers beyond even naming territories to actually defining them. Consequently, toponymic databases circulating on the web contribute to the mapping and ordering of the world by imposing geo-coding methods, namely the formal process of assigning geographic coordinates (latitude/longitude) to an address, via automated processing.

The public authorities are now seeking to reposition themselves with deliberate polices aimed at controlling not only the production of data but, especially, information flows, in order to organize the sharing and dissemination of data considered to be legitimate (standardized).

This analysis of the circulation of Amerindian place names and the institutional blockages to alternatives opened up by the geoweb provides a concrete demonstration of the power plays involved in the regulation of geographic data on the web. What is at stake is the accelerated propagation of a dataset once it is disseminated via a domino effect among components of these increasingly connected web architectures, and, at the same time, the loss caused by the collapse of the tower of Babel of perfect, exhaustive interoperability. These losses, which do not result from technical difficulties but legal choices or the constraints of standardization, are not ambivalent. Analysis of social intentions -now multiple and fragmented - that leads to the inclusion or exclusion of a given dataset demonstrates that it is necessary to perform an in-depth examination of data infrastructures on the web, for these algorithmic black boxes perpetuate and sometimes strengthen the visibility/lack of visibility of dominant/marginal knowledge. Consequently, without seeking to replace place naming studies but rather seeking to prolong them, we propose to increase the number of empirical studies and critical analyses of the processes that affect the diffusion and regulation of place names downstream from their creation and, in so doing, to undertake genuine studies on place name flow. 


\section{Acknowledgments}

This work was supported by the project "GUYNT: The challenges of the Guianas plateau's Governance" with a grant of the French National Research Agency (ref.: ANR-17-CE03-0002).

\section{References}

Brunet R. 2016. Trésor de terroir : les noms de lieux de la France. Paris: Éditions du CNRS.

Collignon, B. 2006. "Inuit place names and sense of place." In Critical Inuit Studies: an anthology of contemporary arctic ethnography, ed. P. Stern and L. Stevenson. Lincoln: University of Nebraska Press. 187-205.

Dalton, C. M. Taylor, L. and Thatcher J. 2016. "Critical Data Studies: A dialog on data and space." Big Data \& Society, 3/1. Available at https://doi.org/10.1177/2053951716648346

Daly, V. 1976. A short history of the Guyanese people, London: Macmillan.

Desbiens C., Rivard E. and Hirt I. 2017. "Nous nous souvenons du territoire : la géographie québécoise face aux mémoires autochtones." Cahiers de géographie du Québec, 61/173: 293-313.

Dodge, M. Kitchin, R. and Perkins R. 2009. Rethinking maps: new frontiers in cartographic theory, London: Routledge.

Duféal M. and Noucher M. 2017. "Des TIC au TOC. Contribuer à OpenStreetMap : entre commun numérique et utopie cartographique", Netcom, network and communication studies, 31-1/2, URL : http://journals.openedition.org/netcom/2635 ; DOI : $10.4000 /$ netcom.2635

Foucault, M. 1980. Power/Knowledge: Selected Interviews and Other Writings 19721977(ed. C. Gordon). Brighton: Harvester.

Giraut, F. and Houssay-Holzschuch, M. 2008. "Néotoponymie : formes et enjeux de la dénomination des territoires émergents." L'Espace Politique, 5/2, Available at: http://journals.openedition.org/espacepolitique/161

Giraut, F. and M. Houssay-Holzschuch. 2016. Place Naming as Dispositif: Toward a Theoretical Framework. Geopolitics, 21:1-21.

Goodchild, M. and Hill, L. 2008. "Introduction to digital gazetteer research." International Journal of Geographical Information Science, 22/10: 1039-1044. 
Goodchild, M. F. 2007. "Citizens as sensors; the world of volounteered geography." GeoJournal. 69/4: 211-221.

Grenand, P. Grenand, F. Joubert, P. and Davy, D. 2017. "Pour une histoire de la cartographie des territoires teko et wayãpi (Commune de Camopi, Guyane française)" , Revue d'ethnoécologie, 11, Available at: http://journals.openedition.org/ethnoecologie/3007

Grenand, P. Joubert, P. Grenand, F. and Davy, D. 2015. Cartes et Toponymes des territoires Teko et Wayãpi, Parc Amazonien de Guyane. Cayenne: CNRS.

Guyot, S. and Seethal, C. 2007. "Identity of Place, Places of Identities: Change of Place Names in Post-Apartheid South Africa." South African Geographical Journal, 89:55-63.

Iliadis, A. and Russo, F. 2016. Critical data studies: An introduction. Big Data \& Society, $3 / 2$.

Kadmon, N. 2000. Toponymy. The Lore, Laws and Language of Geographical Names. New York: Vantage Press.

Leszczynski, A. and Wilson M. 2013. "Theorizing the geoweb." GeoJournal, 78: 915919.

Lézy, E. 2000. Guyane, Guyanes, une géographie « sauvage » de l'Orénoque à I'Amazone, Paris: Belin.

Miller, C. C. 2006. "A Beast in the Field: The Google Maps Mashup as GIS/2." Cartographica. 41/3: 187-199.

Monmonier, M. 2006. From Squaw Tits to Whorehouse Meadows. How Maps Name, Claim and Inflame. Chicago: The University of Chicago Press.

Noucher, M. 2017. Les Petites Cartes du Web. Approche critique des nouvelles fabriques cartographiques. Paris: Éd. Rue d'Ulm - Presses de l'École normale supérieure, $70 \mathrm{p}$.

Nuttall, M. 1991. "Memoryscape: a sense of locality in northwest Greenland." North Atlantic Studies, 1(2): 39-50.

Rose-Redwood, R.S. 2006. "Governmentality, geography, and the geo-coded world." Progress in Human Geography, 30/4: 469-486.

Rouvroy, A. 2011. Technology, virtuality and utopia: governmentality in an age of autonomic computing. In Law, human agency and autonomic computing. Ed. Hildebrandt M. and Rouvroy, A. London: Routledge. 135-156. 
Sui, D. Elwood, S. and Goodchild, M. 2013. Crowdsourcing Geographic Knowledge. Volunteered Geographic Information in theory and practice. Berlin: Springer.

Turner, A. J. 2006. Introduction to Neogeography. O'Reilly Media.

Xu, Jinghai and Nyerges T.L. 2017. "A framework for user-generated geographic content acquisition in an age of crowdsourcing". Cartography and Geographic Information Science 44/2: 98-112. 